\title{
Sub-seafloor sulfide mineralization in the Saldanha hydrothermal field, Mid-Atlantic Ridge (MAR)
}

\author{
Ágata Alveirinho Dias ${ }^{1,2^{*}}$ W. QIU (JOHNSON) ${ }^{1}$ \\ FERNANDO BARRIGA ${ }^{2}$ CHUNHUI TAO ${ }^{3}$ \\ ${ }^{1}$ Institute of Science and Environment, University of Saint \\ Joseph. Macao SAR \\ ${ }^{2}$ Instituto Dom Luiz, University of Lisbon. Portugal \\ ${ }^{3}$ Second Institute of Oceanography, MNR, Hangzhou, China \\ *agata.dias@usj.edu.mo
}

Sulfide mineralization in the Saldanha hydrothermal field is characterized by chalcopyrite $(\mathrm{Ccp})+$ sphalerite $(\mathrm{Sp})+$ pentlandite $(\mathrm{Pn})+$ pyrite $(\mathrm{Py})$ that were precipitated below the seafloor within a highly porous matrix composed mostly of serpentine + talc. These disseminated deposits are capped by an oxyhydroxide crust. In this work, we studied the bulk chemical composition, $\mathrm{Nd}-\mathrm{Pb}$ isotopes and in situ $\mathrm{S}$ isotopes of sulfides on a core $(27 \mathrm{~cm})$ collected in an active area of the Saldanha field, in an attempt to understand the hydrothermal processes and trace the source of the ore-forming minerals.

Our results show a downcore variation in metals (e.g. Cr, Ni, $\mathrm{Co}, \mathrm{Cu} / \mathrm{Zn}, \mathrm{Cu} / \mathrm{Fe}, \mathrm{Zn} / \mathrm{Fe}$ and $\mathrm{Mn} / \mathrm{Fe}$ ) and REE contents and $\mathrm{Nd}$ isotopic composition consistent with sulfide mineralization below the seafloor (particularly evident between 16 and $21 \mathrm{cmbsf}$ ). In the top layers, the geochemical signatures are coherent with physico-chemical conditions resulting from higher water/rock interactions.

$\mathrm{Pb}$ and $\mathrm{Nd}$ isotopic signatures (less radiogenic $\mathrm{Pb}$ isotopic compositions occur between 7 and $21 \mathrm{cmbsf} ; \varepsilon_{\mathrm{Nd}(0)}=+8.57$ to +10.11 , lower $\varepsilon_{\mathrm{Nd}(0)}$ values recorded below $16 \mathrm{cmbsf}$ ) indicate that higher temperature hydrothermal fluid might be produced during the hydrothermal alteration of less enriched mafic rocks at depth and that extensive mixing has occurred in the top layers. In situ $\delta^{34} \mathrm{~S}$ composition of sulfide phases varies from 3.63 to $14.34 \%$ in Ccp, 5.62 to $9.07 \%$ in Pn and -1.37 to $10.47 \%$ in $\mathrm{Py} . \mathrm{\delta}^{34} \mathrm{~S}$ signatures fluctuation along the core is in agreement with the above data. However, the high $\delta^{34} S$ values in the upper layers suggest that ${ }^{34} \mathrm{~S}$ enrichment could be related to reduction of seawater sulfate associated with a complete serpentinization of mantle peridotites at high water/rock ratios. On the other hand, the low $\delta^{34} \mathrm{~S}$ values of ca. $0 \%$ recorded on some Py grains at $20 \mathrm{cmbsf}$ indicate dominant mantle $\mathrm{S}$ sources that leached from mafic rocks by interaction with high temperature hydrothermal fluids. Overall, our results show that Saldanha sulfide mineralization is primary derived from high temperature fluids with magmatic signatures but that interaction of these fluids with ultramafic rocks may also take place. 